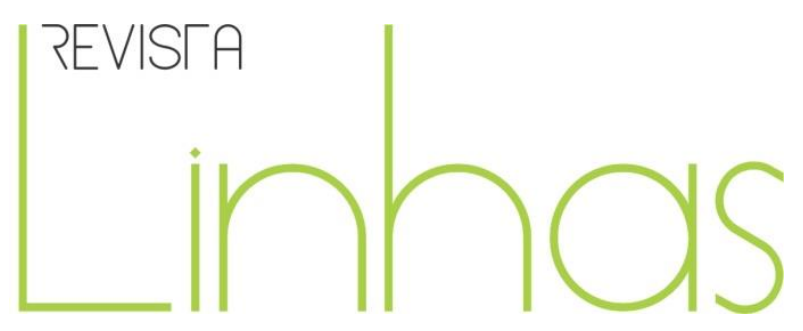

\title{
Imaginário das águas especulares: potencializando significados ${ }^{1}$
}

\begin{abstract}
Resumo
O espelho é suporte para o simbolismo na ordem do conhecimento e que derivou especulação. Especular, portanto, significa estudar, observar com atenção. Meditar, contemplar. Este consiste um grande desafio para pesquisadores e pesquisadoras que estudam imaginário, gênero e sexualidade: tentar analisar os detalhes, as minúcias de temas que são paradoxais, enigmáticos, ambíguos tais como o espelho - que é símbolo da pureza, da verdade, da sinceridade, mas tem a ambiguidade das verdades e mentiras por gerar enganos e imagens deturpadas. Este texto pretende problematizar os devaneios diante do reflexo das águas, tais como, nas Metamorfoses do poeta Ovídio, a história de Narciso. O espelho da Alice no País das Maravilhas e o espelho mágico da bruxa da Branca de Neve. Gilbert Durand associa o reflexo da água ao complexo de Ofélia da obra Hamlet, de William Shakespeare. Essas reflexões potencializam a educação para as sexualidades e as relações de gênero.
\end{abstract}

Palavras-chave: Imaginário das Águas; Espelhos; Gênero; Sexualidade.

\author{
Cláudia Maria Ribeiro \\ Universidade Federal de Lavras - \\ UFLA - MG/Brasil \\ ribeiro@ded.ufla.br
}

\section{Alberto Filipe Araújo \\ Universidade do Minho - Braga/Portugal afaraujo@ie.uminho.pt}

\footnotetext{
Para citar este artigo:

RIBEIRO, Cláudia Maria; ARAÚJO, Alberto Filipe. Imaginário das águas especulares: potencializando significados. Revista Linhas. Florianópolis, v. 17, n. 34, p. 132-148, maio/ago. 2016.
}

\section{DOI: $10.5965 / 1984723817342016132$}

http://dx.doi.org/10.5965/1984723817342016132

\footnotetext{
${ }^{1}$ Este artigo teve o apoio financeiro da Fundação para Ciência e Tecnologia (FCT - Lisboa/Portugal) e do programa de financiamento POCH (Programa Operacional Capital Humano): financiamento comparticipado pelo Fundo Social Europeu e por fundos nacionais do Ministério da Educação e Ciência (MEC - Lisboa/ Portugal) (2015-2016).
} 


\title{
Imaginary of specular waters: empowering meanings
}

\begin{abstract}
The mirror is support for the symbolism in the order of knowledge and which derived speculation. Speculate, therefore, means to study, observe carefully. Meditate, contemplate. This is a major challenge for researchers who study imaginary, gender and sexuality: try to analyze the details, the minutiae of issues that are paradoxical, enigmatic, ambiguous, such as the mirror - which is a symbol of purity, truth, sincerity, but has the ambiguity of truth and lies to generate deceit and misrepresented images. This paper intends to discuss the reverie front of the reflection of the water, such as the poet Ovid's Metamorphoses, the Narcissus story. The mirror of Alice's Adventures in Wonderland and the magic mirror of the Evil Queen Witch from Snow White book. Gilbert Durand joins the reflection of the water to Ophelia complex on the play Hamlet by William Shakespeare. These reflections empower education for sexuality and gender relations.
\end{abstract}

Keywords: Imaginary Waters; Mirrors; Gender; Sexuality. 


\section{Devaneios diante do reflexo das águas}

Bachelard (1989, p. 28) diz que "perto do riacho, em seus reflexos, o mundo tende à beleza. O narcisismo, primeira consciência de uma beleza, é, portanto, o germe de um pancalismo” (...) “quando simpatizamos com os espetáculos da água, estamos sempre prontos a gozar de sua função narcísica. A obra que sugere essa função é imediatamente compreendida pela imaginação material da água" (BACHELARD, p. 30). Navegando pelos reflexos das águas estamos cientes da complexidade do tema abordado e assumimos que este objeto de estudo polissêmico não se esgotará por aqui².

Iniciamos com o mito de Narciso que foi narrado por Ovídio, no Livro Terceiro da sua obra Metamorfoses (1841), (Grimal, 1982, p. 322-323; Biedermann, 1996, Moore, 1996, p. 75-83). Segundo a narrativa mítica, Narciso é filho do rio Cefiso e da ninfa Liríope (rio da Beócia), e que acabou por se afogar nas águas/espelho do lago em que admirava a sua própria imagem, desde que se apaixonou pela sua imagem refletida nas águas cristalinas desse mesmo lago. Esta passagem do mito narra uma história sobre o autoconhecimento e o amor por si - próprio, ilustrando assim a dimensão da mesmidade do humano, isto é, o seu lado egocêntrico, egoísta e individualista.

Na sua obra A era do Vazio. Ensaio sobre o individualismo contemporâneo, Lipovetsky (1988, p. 47) refere que "uma geração gosta de se reconhecer e de descobrir a sua identidade numa grande figura mitológica ou lendária, que reinterpreta em função dos problemas do momento". E o autor adianta que os espelhos da condição moderna foram, entre outros, Prometeu e Fausto, enquanto atualmente é Narciso que simboliza a cultura em que vivemos. Trata-se, na sua perspectiva, de uma mutação antropológica que instaura um novo estágio do individualismo:

O narcisismo designa a emergência de um perfil inédito do indivíduo nas suas relações consigo próprio e com o seu corpo, com outrem, com o mundo e com o tempo, no momento em que o "capitalismo" autoritário dá a vez a um capitalismo hedonista e permissivo. (LIPOVETSKY 1988, p. 48)

\footnotetext{
${ }^{2}$ Nossa intenção é desenvolver e aprofundar, interdisciplinarmente, o tema que agora nos ocupa, em trabalhos ulteriores. $O$ estudo atual representa tão-somente um esboço que pretendemos seja frutífero.
} 
Segundo Lipovetsky, (1988, p. 48) em paralelo com a revolução informática acontece uma revolução interior: "um fascínio sem precedentes pelo autoconhecimento e pela autorrealização”. As paixões do indivíduo são canalizadas no sentido do Eu que se torna a preocupação central e contribui para o aprofundamento e a fragmentação social. Neste sentido, alastra a nova ética permissiva e hedonista: "o esforço deixou de estar na moda, o que significa coerção ou disciplina austera desvalorizadas em proveito do culto do desejo e da sua realização imediata" (LIPOVETSKY, 1988, p. 54). Recorrendo a Nietzsche, o autor explica o enfraquecimento da vontade em resultado da pluralidade e da desagregação dos impulsos que aniquilam os sistemas psíquicos organizados e derretem a rigidez de uma sociedade dirigida, em nome de uma sociedade que agora é comandada do interior, cultivando a singularidade e a diferença. Assistimos, pois, a uma fragmentação crescente que faz explodir a solidez que restava da sociedade moderna, estimulando a dispersão e a não-diretividade. A subjetivação e a psicologização invadem a sociedade pós-moderna, promovendo o "culto da personalidade":

Com efeito - afirma Lipovetsky - é da deserção generalizada dos valores e finalidades sociais, implicada pelo processo de personalização, que o narcisismo surge. Desafeção dos grandes sistemas de sentido e hiperinvestimento do Eu caminham a par: nos sistemas de "rosto humano" funcionando à força de prazer, bem-estar, desestandardização, tudo concorre para a promoção de um individualismo puro, ou, por outras palavras, psi, desembaraçado dos enquadramentos de massa e orientado para a valorização generalizada do sujeito. (LIPOVETSKY, 1988, p. 50)

Mas esse sujeito que revela uma paixão por si e se mostra insensível aos papéis sociais, manifesta também uma obsessão pela revelação íntima do Eu. Sacrificando a privacidade, o indivíduo procura desvendar a sua personalidade e exprimir os seus sentimentos em nome de uma verdade pessoal e quebrando as barreiras sociais que protegem as pessoas umas das outras, garantindo a civilidade.

O indivíduo afirma-se pela sua indiferença aos valores sociais e morais tradicionais e só a esfera privada sai vitoriosa das transformações operadas pelos desejos dos indivíduos: "Ter relações inter-individuais sem ligação profunda, não se sentir vulnerável, desenvolver a sua independência afetiva, viver sozinho, tal seria o perfil de Narciso" 
(1988, p. 72). De acordo com este perfil, que experiencia uma "incapacidade de sentir as coisas e os seres" (1988, p. 72) e, correlativamente uma "impossibilidade de sentir" (1988, p. 72), o mito de Narciso aparece, nas palavras de Lipovetsky, como "estratégia do vazio" (1988, p. 72). Um vazio caracterizado pela superficialidade das relações, pela indiferença face ao outro, pelo "vazio emotivo", pois, o narcisismo como sublinha Thomas Moore, é “um estado em que uma pessoa não gosta de si própria” (1996, p. 89), e, consequentemente, a incapacidade de sentir amor por si próprio impede-o de se relacionar saudavelmente consigo e com o Outro. Numa palavra, a experiência da alteridade, isto é, o estabelecimento de laços afetivos com o mundo, está-lhe vedada. Neste contexto, o narcisismo é encarado sob a perspectiva da "perturbação caracterial" (1988, p. 71) e da desordem emocional, pois, como qualidade-sombra (Jung), leva-nos a centrar a nossa atenção sobre nós próprios, esquecendo o mundo cósmico e pessoal. 0 narcisismo aparece, assim, como desprovido de alma, na medida em que se traduz pela “absorção do eu por si próprio, desprovida de calor humano e de amor" (MOORE, 1996, p. 77).

Especular... Navegando pelas contradições! Fazer borbulhar paixões em Narciso e sua simbologia (BETTINI, 2010. p. 5-40); mas também pelos espelhos mágicos que respingam nonsenses - o espelho da Alice no País das Maravilhas; o espelho mágico da bruxa de Branca de Neve e as paixões refletidas nos espelhos d'água de Ofélia, personagem de Sheakespeare.

\section{Espelho da Alice no país das maravilhas}

Alice... Curiosa? Forasteira? Ávida por viver? Corajosa? Determinada?

Escrita para leitores e leitoras britânicos/as de séculos atrás na Inglaterra Vitoriana. Poderíamos afirmar um nonsense despropositado do autor? Lewis Carroll era um apaixonado por reflexos especulares. No segundo livro Alice: Através do Espelho, o autor navega por entre os espelhamentos no tabuleiro de xadrez. Na edição comentada por Martin Gardner (2002) encontramos:

As atordoantes mudanças de tamanho que Alice experimenta no primeiro livro são substituídas por mudanças igualmente atordoantes de lugar, ocasionadas, é claro, pelos movimentos das peças de xadrez pelo 
tabuleiro. Por uma feliz coincidência, o xadrez se harmoniza perfeitamente com o tema do espelhamento. Não só torres, bispos e cavaleiros vêm aos pares, como a disposição assimétrica das peças de um jogador no início de um jogo (assimétrica por causa das posições de rei e rainha) é um espelhamento exato da disposição das peças do adversário. Por fim, a lógica incomum do jogo de xadrez combina muito bem com a lógica louca do mundo do espelho. (GARDNER, 2002, p. 132)

Cada detalhe da obra Alice no País das Maravilhas pode incitar-nos a mergulhar nas águas turbulentas da cultura enquanto prática de produção, de criação, de significação que têm estreita ligação com os jogos de saber-poder-verdade em que as relações sociais são relações de poder. A leitura de Alice pode ser feita a partir de inúmeras "chaves de leitura". Uma delas remete aos estudos foucaultianos (1988) que propõem a capilaridade, ou seja, o poder sendo exercido, o que requer estratégias, manobras, técnicas, disposições inundando as entrelinhas de cada página de Lewis Carroll.

Quantas estratégias de saber e de poder perpassam as pedagogias culturais. Se olharmos as histórias de Alice com a lente da produção de conhecimento sobre sexualidade, enxergaremos o incitar a falar sobre, as perplexidades frente aos discursos que exercem poderosos controles, mas também indicam possibilidades de resistências, instigando a pensar os processos de produção das diferenças e a provisoriedade das verdades. Como Alice que atravessa o espelho com a pergunta: o que se encontra quando atravessa o espelho? Repetimos: o que encontramos quando atravessamos o espelho da cultura? Muitíssimas possibilidades para pensar as relações de gênero e sexualidade.

O autor apresenta essa enxurrada de histórias - "num certo sentido, o próprio nonsense é uma inversão sanidade-insanidade. O mundo usual é virado de cabeça para baixo e de trás para frente; torna-se um mundo em que as coisas tomam todos os rumos, menos os esperados" (GARDNER, 2002, p. 138). Ora, uma leitura assim não paralisa o pensamento. Instigante discutir as relações de gênero e sexualidade virando este mundo de cabeça para baixo possibilitando o surgimento de novas formas de habitar o mundo: "Que coisa estranha é um espelho! E que afinidade assombrosa existe entre ele e a imaginação de um homem! (e acrescentaríamos de uma mulher!)" (excerto do romance de MacDonald de 1858 Phantastes. In: GARDNER, 2002, p. 140).

Espelhos, jogos de xadrez, vida às avessas!! 


\section{Branca de Neve: a mais bela de todas ${ }^{3}$}

Originário da tradição oral alemã, foi compilado pelos Irmãos Grimm e publicado entre 1812 e 1822. Várias foram as releituras e adaptações. Nossa proposta é discutir o filme que, no Brasil foi intitulado somente: Branca de Neve.

Em quais imagens simbólicas esse filme faz-nos surfar para entrelaçá-las às relações de gênero e sexualidade? No início e fim do filme o imaginário das águas faz-se presente. Mircea Eliade (1977, p. 231-232). diz que "as águas simbolizam a totalidade das virtualidades; elas são fons et origo, a matriz de todas as possibilidades de existência"

A neve do começo do filme é a água enregelante. E, no fim, o gênio, que foi salvo na neve pelo pai de Branca de Neve, caminha por elas. Depois de toda a trama acontecida no filme poderíamos dizer que "o gênio acompanha cada homem, como seu duplo, seu daimon, seu anjo da guarda, seu conselheiro, sua intuição, a voz de uma consciência supra-racional" (CHEVALIER e GHEERBRANT, 1998, p. 468).

Gênio que, por não ser o anjo da guarda, foi responsável por tantos desencontros no decorrer do filme. Ele que realiza os desejos do pai de Branca de Neve e que também é responsável pela transformação da bruxa em rainha. Linda! Sedutora! Que possui um espelho mágico; que tem uma sala enorme de espelhos; que faz do espelho seu fiel aliado na certificação de sua beleza! Que magicamente mantém seu esposo sob seu controle quando um estilhaço do espelho mágico encontra-se em seus olhos.

“Espelho... espelho meu!" O que está refletido pelo olhar da bruxa, madrasta de Branca de Neve? Que desespero causa a beleza de uma pele tão alva e lábios tão vermelhos? Na cena inicial do filme, uma gota de sangue cai dos dedos da mãe justamente sobre a neve branca e anuncia toda a simbologia da cor vermelha: “Universalmente considerado como o símbolo fundamental do princípio da vida, com a sua força, seu poder e seu brilho, o vermelho cor de fogo e de sangue” (Id. p. 944). As seduções na arte erótica navegam pelas cores vermelhas: roupas íntimas, cartazes publicitários, luz dos bordéis “convites que dizem respeito à transgressão da mais

\footnotetext{
${ }^{3}$ Snow White: the fairest of them all. Título original do filme Americano-canadense de aventura e fantasia, coescrito e dirigido pela cineaste Caroline Thompson e produzido pela Hallmark Entertainment.
} 
profunda proibição (...) lançada sobre as pulsões sexuais, a libido, os instintos passionais" (Id., p. 944). As tonalidades da cor vermelha têm sua simbologia:

O vermelho-claro, brilhante, centrífugo, é diurno, macho, tônico, incitando à ação, lançando como um sol, seu brilho sobre todas as coisas, com uma força imensa e irredutível. O vermelho-escuro, bem ao contrário, é noturno, fêmea, secreto e, em última análise, centrípeto. (Id. p. 944)

Ambivalências, contradições, múltiplas simbologias que nos incitam às discussões das relações de gênero e sexualidade. A aparente morte da Branca de Neve estava envolta na cor vermelha de outra forte simbologia: a da maçã: "consumida por Adão e Eva; da maçã do Cântico dos Cânticos que representa, ensina Orígenes, a fecundidade do Verbo divino, seu sabor e seu odor" (Id., 572).

O sangue - veículo da vida - também participa da simbologia do vermelho. Uma gota dele anunciou, no início do filme, Branca de Neve, a sua beleza, nobreza e generosidade. E paixão!

Paixão até aqui de Narciso, de Alice, da Branca de Neve e da bruxa-madrasta. Conforme anunciado neste texto, falta Ofélia.

\section{Complexo de Ofélia}

Gilbert Durand associa o reflexo da água ao "complexo de Ofélia, uma vez que mirar-se é, de algum modo, - 'ofelizar-se' - e participar da vida das sombras, nesse campo de lágrimas que se assemelha ao rio da morte e do afogamento" (COSTA e CRUZ, 2006). Mas quem é a personagem Ofélia? Na obra Hamlet de William Shakespeare (1564 - 1623) uma jovem donzela que apesar de sua aparência recatada e sua submissão ao pai e ao irmão é uma mulher forte e determinada que tem suas inquietações e mistérios. Seu nome - Ofélia - de origem grega, significa “ajuda, assistência”. Foi rotulada de louca. É a representação das mulheres de seu período histórico da passagem da Idade Média para o Renascimento em que as relações de gênero, sexualidade, raça, classe social e, 
principalmente as mudanças no catolicismo, anglicanismo e protestantismo geravam outros códigos éticos:

$\mathrm{Na}$ Inglaterra de Shakespeare, o homem podia exercer uma grande variedade de papéis de acordo com suas possibilidades e capacidades; o desempenho social da mulher, no entanto, era bastante limitado. Sua identidade derivava exclusivamente do sexo ao qual pertencia: podia ser mãe, esposa ou viúva; dama ou criada; virgem, prostituta ou bruxa. (GONÇALVES, 2010, s/p)

Ofélia era uma donzela e transforma-se em uma ninfa das águas. Esse momento da peça foi muito retratado em pinturas apresentando a ambiguidade que cerca sua morte: proposital ou acidental?

\begin{abstract}
A água que é a pátria das ninfas vivas é também a pátria das ninfas mortas. É a verdadeira matéria da morte bem feminina. Desde a primeira cena entre Hamlet e Ofélia, Hamlet - seguindo nisso a regra da preparação literária do suicídio - como se fosse um adivinho que pressagia o destino, sai de seu profundo devaneio murmurando: "Eis a Bela Ofélia! Ninfa, em tuas orações, lembra-te de todos os meus pecados". (Hamlet, ato III, c. I). Assim Ofélia deve morrer pelos pecados de outrem, deve morrer no rio, suavemente, sem alarde. Sua curta vida é já a vida de uma morta. (BACHELARD, 1989, p. 84)
\end{abstract}

Também nas primeiras cenas da peça Hamlet, de Shakespeare - apesar de Ofélia já ser uma moça - o pai e o irmão chamam a sua atenção para a sua fragilidade e infantilidade:

Este fato da busca por sua própria identidade é reverberada através da água densa e coberta por lodo. Ofélia usa a água como espelho, mas não consegue ver a sua imagem refletida porque há lodo na água. Muito lodo. Ao fazer esta opção, é como se o pintor estivesse nos alertando que Ofélia não sabe quem é a si própria, uma vez que não consegue se enxergar. Ela apenas se vê através das falas do pai e do irmão, que se referem a ela como "criança inexperiente" (OLIVEIRA, 2008, p. 4) 
Elinês Oliveira (2008) escreveu o texto "Assim como o teatro é a pintura": representações de Ofélia no cenário Pré-Rafaelita, na íntegra no espaço Inundando de Saberes do Museu Imaginário das Águas, Gênero e Sexualidade ${ }^{4}$. O texto discute como a personagem Ofélia foi retratada por três pintores da escola Pré-Rafaelita, a saber: John Everett Millais, Arthur Hughes e Dante Gabriel Rossetti. A autora, a partir de suas análises, afirma que os pintores estudados possibilitaram enxergar a personagem por diferentes ângulos. E diz que "é este o seu encanto e o seu desafio ao longo deste continuum semiótico sempre em devir, no qual estamos inseridos". Lembremos que ela mesma nos advertiu 'nós sabemos o que somos, mas não o que poderemos vir a ser'.

O grifo é da autora, mas assumimos também como nosso! Haja devir para anunciar novas formas de sociabilidade para as relações de gênero e expressões das sexualidades mais libertárias e respeitosas! Assim, escolhemos uma das obras de John William Waterhouse para problematizar essas temáticas.

Esse pintor era apaixonado pela natureza e por figuras femininas - heroínas e mulheres fatais. Pintou cenas clássicas e míticas. Nasceu em Roma em 1849 e seguiu com o pai para a Inglaterra em meio ao contexto da Revolução Industrial. Optou por não retratar a pobreza da época, mas as histórias de amor trágicas inspirado em pré-rafaelitas e pintores clássicos. Pintou três vezes Ofélia. Seus quadros não a representam como várias pinturas que a retratam nos séculos XIX e XX: louca ou morta.

Waterhouse representa Ofélia em seu conflito entre o que querem que ela seja e o que ela deseja ser. Camati (2014) descreve as cenas que caracterizam sua vida:

A intimidação sexual de Ofélia já se evidencia na terceira cena do primeiro ato: vemos como ela é sugestionada para submeter-se às regras do patriarcado, manipulada por ambos, seu pai e seu irmão, que lhe ordenam a não confiar em seus sentimentos e desejos. A fragmentação de sua mente é o resultado de atitudes e mensagens contraditórias que ela não consegue conciliar: ela é usada e confundida por todos os homens de seu convívio, seu pai, seu irmão, o rei Cláudio e o próprio Hamlet. Laertes tenciona colocá-la num pedestal como um objeto estético, encarnando seu ideal de castidade feminina; Polônio objetiva transformá-la num completo autômato, sempre pronta para obedecer as

\footnotetext{
${ }^{4}<$ http://www.fastore.pt/museu>.
} 
suas ordens, uma mercadoria a ser negociada em proveito próprio; Cláudio a vê como um instrumento para sondar os propósitos de seu sobrinho; e Hamlet não hesita em insultá-la na cena do convento, descarregando nela toda a sua fúria e ansiedade motivada pela sua percepção neurótica da conduta de sua mãe. Ela não tem autonomia de escolha, pensamento e ação, e todos se mostram completamente alheios às suas necessidades e desejos. Completamente circunscrita pelo poder patriarcal, Ofélia é obrigada a reprimir não apenas a sua sexualidade, mas também a anular a sua identidade, a qual, tendo sido construída tomando como referência exclusivamente a vontade dos outros, não teve oportunidade de florescer (CAMATI, 2014, p. 4)

O texto de Shakespeare é fonte inesgotável de enunciados, concebendo-os aqui no referencial foucaultiano multiplicando relações: "Pluridiscursividade, heterogeneidade discursiva, interdiscurso são algumas palavras ou expressões que se referem, basicamente, à dispersão dos enunciados" (FISCHER, 2001, p. 206). Interessa-nos pensar as condições de existência da produção de Hamlet e da pintura de Ofélia por Waterhouse e não analisar o que está por trás de ambos ou o que se queria dizer.

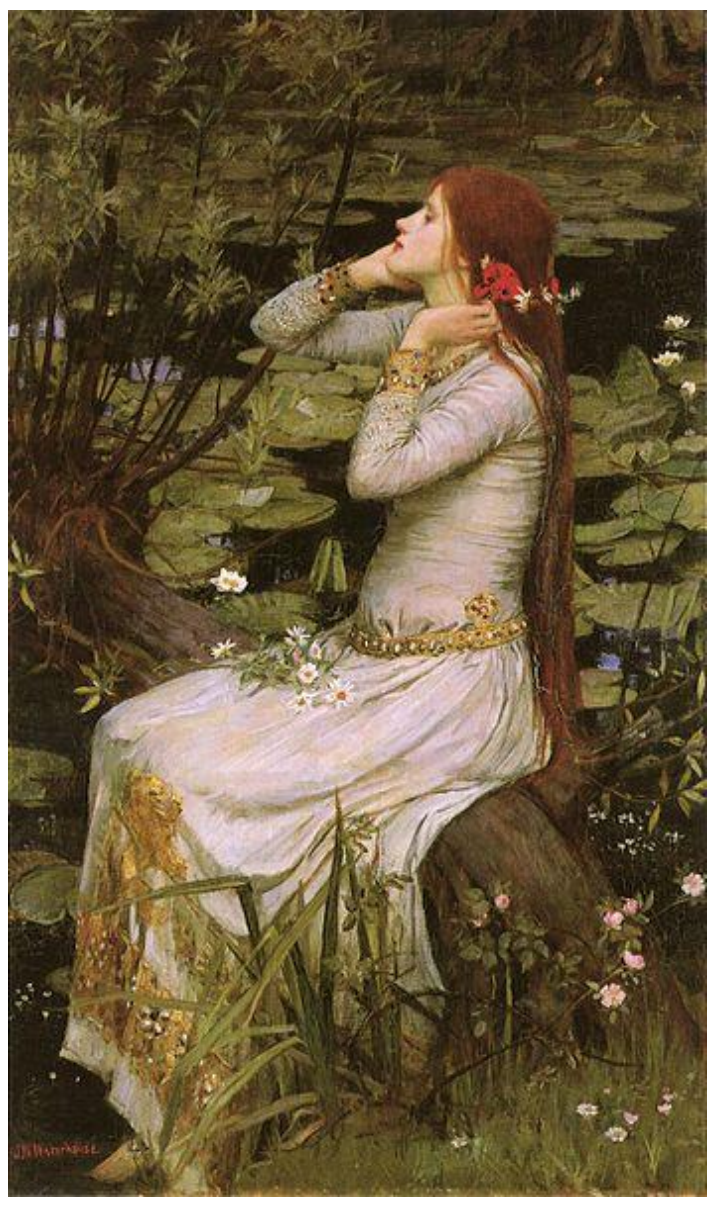

Ofélia - 1894 - John William Waterhouse. 
Assim, autorizamo-nos a navegar pela pluridiscursividade relacionando a Ofélia pintada por Waterhouse, em 1894, com a lenda da Vitória-Régia, que é uma lenda brasileira de origem indígena tupi-guarani. Algo no quadro do pintor chamou nossa atenção: seria a planta vitória-régia compondo a cena de Ofélia à beira do lago? Devaneios de uma mulher submissa e forte. Palavras e imagens borbulhantes de significados! A planta foi levada à Inglaterra por um pesquisador inglês em homenagem à Rainha Vitória em finais do século XIX. Ela subiu ao trono em 1837. O Jardim Botânico Real em Kew - Londres, expõe a exuberância da planta aquática proveniente da Amazônia. Ora, a obra de arte em tela data de 1894. Poderíamos, sim, afirmar que Waterhouse pinta essa planta e entrelaçar Ofélia com a lenda:

Conta a lenda que uma índia chamada Naiá, ao contemplar a lua (Jaci) que brilhava no céu apaixona-se por ela. Segundo contavam os indígenas, Jaci descia a terra para buscar alguma virgem e transformá-la em estrela do céu. Naiá ao ouvir essa lenda, sempre sonhava em um dia virar estrela ao lado de Jaci. Assim todas as noites, Naiá saía de casa para contemplar a lua e aguardar o momento da lua descer no horizonte e sair correndo para tentar alcançá-la. Todas as noites Naiá repetia essa busca, até que uma noite Naiá, decide mais uma vez tentar alcançar a lua. Nessa noite Naiá vê o reflexo da lua nas águas do igarapé e sem exitar mergulha na tentativa de tocá-lo e acaba afogando-se. Jaci se sensibiliza com o esforço de Naiá e a transforma na grande flor do Amazonas, a Vitória Régia, que só abre suas pétalas ao luar. (www.sohistoria.com.br/lendasemitos/regia)

Para Naiá, ocorreu o que Gilbert Durand denomina de complexo de Ofélia, ou seja, participar da vida das sombras no lago da morte e do afogamento. A índia viu-se sem poder se tocar apaixonada que estava pela lua. Mergulhou, afogou-se e foi transformada em flor: a vitória-régia. A flor chamada de "Estrela das Águas".

A magia na contemplação das águas, para as duas mulheres, consistia em fonte de revelação do ser. O que ambas enxergavam no espelho: Naiá, a sua amada; e Ofélia, um profundo desencanto com a sua condição de mulher submissa sem querer sê-lo.

Tristezas diferentes frente ao espelho do lago, mas ambas pela paixão. Ambas fortes e determinadas. Ofélia vivendo no contexto do século XVII cercada pelos preceitos 
morais da época. Vários estudos (GONÇALVES, 2010; CAMATI, 2014; SANTOS, 2009; KOBS, 2009; PERET, 2015) foram realizados focando a peça Hamlet e discutindo as relações de gênero na Inglaterra e na Idade Moderna. Mergulhar nesses estudos faz-nos pensar que:

a sexualidade é algo que nós mesmos criamos - ela é nossa própria criação, ou melhor, ela não é a descoberta de um aspecto secreto de nosso desejo. Nós devemos compreender que, com nossos desejos, através deles, se instauram novas formas de relações, novas formas de amor e novas formas de criação. (FOUCAULT, 2004, p. 260)

Especular... Observar com atenção... Quanta beleza às margens do lago! E as possibilidades para imbricar as histórias que navegam pelas transformações. Ofélia transforma-se em ninfa das águas. Naiá em Estrela das Águas. Especular as relações de poder. Cada texto cultural traz consigo saberes que produzem efeitos de verdade:

\begin{abstract}
Saber e poder estão diretamente implicados; que não há relação de poder sem constituição correlata de um campo de saber, nem saber que não suponha e não constitua, ao mesmo tempo, relações de poder [...] Resumindo, não é a atividade do sujeito de conhecimento que produziria um saber, útil ou arredio ao poder, mas o poder-saber, os processos e as lutas que o atravessam e que o constituem, que determinam as formas e os campos possíveis do conhecimento. (FOUCAULT, 1989, p. 30)
\end{abstract}

Emaranhados nas relações entre saber-poder-verdade, afirmamos que lendas, peças de teatro, músicas, filmes incitam a pensar: "A realidade social é também uma construção. O estudo sistemático das produções do imaginário efetivo propicia o acesso a aspectos mais profundos dessa realidade, disfarçados pela roupagem colorida do fantástico" (AUGRAS, 2009, p. 10).

Essas produções do imaginário - e focamos na personagem Ofélia de Shakespeare - que "reúnem o novo, o antigo e o atemporal" (PERET, 2015, p. 1). A educação para as sexualidades e as relações de gênero tem farto material nas iconografias, nas lendas, nos mitos nos quais borbulham temas como: “lealdade, amor, honra, família, honestidade, 
ambição, traição, preconceito, loucura, fronteiras socioculturais, tradições e transgressões" (PERET, 2015, p. 2).

\section{Potencializando significados: Educação para as sexualidades e relações de gênero}

O imaginário na obra de Gilbert Durand é um conjunto vasto de significados, fantasmas, lembranças, sonhos, devaneios, crenças, mitos, romance, ficção (TEIXEIRA e ARAÚJO, 2011, p. 41). Inventariar os recursos do imaginário constitui-se em imenso desafio para a educação, para as sexualidades e relações de gênero. Assim, ativamos “fantasias, mitos, utopias como forma de superar o falso conflito entre razão e imaginação" (ARAÚJO, ARAÚJO e RIBEIRO, 2012, p. 14). O conceito de imaginário é interdisciplinar: filosofia, teologia, psicologia, sociologia, etnografia, psicanálise, teorias estéticas, literárias, linguísticas (ARAÚJO e ARAÚJO, 2009).

E o conceito de sexualidade? Ela faz parte da liberdade em nosso usufruto deste mundo. "Sujeitos individuais ou coletivos têm diante de si um campo de possibilidades de diversas condutas, diversas reações e diversos modos de comportamento podem acontecer" (FOUCAULT, 1995, p. 244).

As águas refletindo Narcisos, Alices, Brancas de Neve e Ofélias encharcaram as dimensões sociais da sexualidade. O período vitoriano foi citado como fundamental para a compreensão de suas complexidades:

Havia, de fato, uma grande dose de hipocrisia moral, já que os indivíduos (especialmente homens) e a sociedade aparentavam respeitabilidade, mas faziam algo bem diverso. A sexualidade das mulheres era severamente regulada para assegurar a "pureza", mas ao mesmo tempo, a prostituição era abundante. As doenças venéreas representavam uma grande ameaça à saúde, mas eram enfrentadas através de tentativas de controlar e regular a sexualidade feminina ao invés da masculina. (WEEKS, In LOURO, 2001, p. 53)

Esse campo de possibilidades de diversas condutas e as conexões com ontens, hojes e amanhãs podem instigar pensares, especulações. Terminamos com a pergunta de 
Peret (2015, p. 13): quantas vezes será preciso Ofélia enlouquecer e se matar, para que entendamos que a pressão social e mesmo familiar sobre a mulher - e, por extensão, sobre a pessoa homossexual, bissexual, travesti, transexual - ainda é imensa, cruel e, muitas vezes, tem resultados fatais?

\section{Referências}

ARAÚJO, Alberto Filipe; MACHADO, Joaquim; RIBEIRO, José Augusto. As lições de Pinóquio. Estou farto de ser sempre um boneco. Curitiba, PR: Editora CRV, 2012.

ARAÚJO, Alberto Filipe; MACHADO, Joaquim; RIBEIRO, José Augusto. Imaginário educacional: figuras e formas. Niterói, RJ: Intertexto. 2009.

AUGRAS, Monique. Imaginário da magia: magia do imaginário. Petrópolis, RJ: Vozes; Rio de Janeiro: Editora PUC, 2009.

BACHELARD, Gaston. A Água e os sonhos: ensaio sobre a imaginação da matéria. Trad. de Antonio de Pádua Danesi. São Paulo: Martins Fontes, 1989. Coleção Tópicos.

BIEDERMANN, Hans. Encyclopédie des Symboles. Trad. par Françoise Périgant et al. Paris: La Pochothèque-Le Livre de Poche. 1996. Édition française établie sous la dir. de Michel Cazenave.

BETTINI, Maurizio; PELLIZER, Ezio. Le mythe de Narcisse. Trad. de Jean Bouffartigue. Paris: Belin, 2010. 
CAMATI, Anna Stegh. Questões de gênero e sexualidade na época e na obra de Shakespeare. Revista Scripta Uniandrade, v. 12, n. 2, jul-dez 2014.

CARROL, Lewis. Aventuras de Alice no país das maravilhas \& através do espelho. Edição Comentada. Rio de Janeiro: Jorge Zahar Ed., 2002.

CHEVALIER, Jean; GHEERBRANT, Alain. Dicionário dos símbolos: mitos, sonhos, costumes, gestos, formas, figuras, cores, números. Trad. dede Cristina Rodriguez e Artur Guerra. Lisboa: Editorial Teorema, 1982.

CHEVALIER, Jean; GHEERBRANT, Alain. Dicionário dos símbolos: mitos, sonhos, costumes, gestos, formas, figuras, cores, números. Trad.de Vera da Costa e Silva et al. Rio de Janeiro: José Olympio, 1998.

COSTA, Sueli Aparecida da; CRUZ, Antonio Donizete da. A poesia e o fantástico mundo do espelho. Espéculo. Revista de estudios literarios. Universidade Complutense de Madrid. 2006. Disponível em:

<www.pedientedeimigracion.ucm.es/info/especulo/numero34/espelho.html.> . Acesso em 04/02/2014.

ELIADE, Mircea. Tratado de história das religiões. Trad. de Natália Nunes e Fernando Tomaz. Lisboa: Ed. Cosmos, 1977.

FISCHER, Rosa María Bueno. Foucault e a análise do discurso em educação. Cadernos de Pesquisa, n. 114, p. 197-223, nov., 2001. Disponível em:

$<$ www.scielo.br/pdf/cp/n.114/aogn114.pdf >. Acesso em 06/02/2016.

FOUCAULT, Michel. História da sexualidade I: a vontade de saber. Trad.de Maria Thereza da Costa Albuquerque e J.A. Guilhon Albuquerque. Rio de Janeiro: Edições Graal. 1988.

FOUCAULT, Michel. Vigiar e Punir. Petrópolis: Vozes, 1989.

FOUCAULT, Michel. O sujeito e o poder. In: DREYFUS, Hubert; RABINOW, Paul. Michel Foucault: uma trajetória filosófica. Rio de Janeiro: Forense Universitária, 1995, p. 231-249.

FOUCAULT, Michel. Michel Foucault, uma entrevista: sexo, poder e a política da identidade. Verve - Revista do NuSol, São Paulo: Pós-Graduação em Ciências Sociais, Pontifícia Universidade Católica, n. 5, p. 260-277, 2004.

GONÇALVES, Meire Lisboa Santos. A mulher Ofélia - um contraste entre o natural e o social http://www.ufsj.edu.br/portal2-

repositorio/File/vertentes/v.\%2019\%20n.\%202/Meire_Lisboa.pdf

GRIMAL, Pierre. Dicionário da mitologia grega e romana. Rio de Janeiro: Bertrand Brasil, 1982. 
KOBS, Verônica Daniel. Um estudo sobre Hamlet: morte - causa e consequência. Revista Scripta Uniandrade. Curitiba, PR. n. 7. Ano 2009. p. 121.

LIPOVETSKY, Gilles. A Era do vazio: ensaio sobre o individualismo contemporâneo. Trad. de Miguel Serras Pereira e Ana Luísa Faria. Lisboa: Relógio D’Água Editores. 1989.

MOORE, Thomas. O Sentido da alma: como desenvolver a dimensão profunda e sagrada da vida quotidiana. $2^{\text {a }}$. Ed. Trad. de Susana Silva. Lisboa: Planeta Editora. 1996.

NIETZSCHE, Friedrich. Genealogia da moral: uma polêmica. São Paulo: Cia. das Letras, 1998.

OLIVEIRA, Elinês de Albuquerque Vasconcelos e. "Assim como o teatro é a pintura": representações de Ofélia no cenário Pré-Rafaelita. In CONGRESSO INTERNACIONAL DA ABRALIC, XI, Anais... Tessituras, Interações, Convergências. São Paulo, USP, 2008. www.abralic.org.br/anais/cong2008/AnaisOnline/simposios/pdf/032/ELINES_OLIVEIRA.pd f. Acesso em 05/02/2014.

OVÍDIO. Metamorfoses. Trad. Antonio Feliciano de Castilho. Lisboa: Imprensa Nacional, 1841.

PERET, Luiz Eduardo. Queer Shakespeare: transgressão, sexualidade e identidades de gênero na obra do Bardo. Revista Periódicus, 2 ${ }^{a}$ ed. nov. 2014 - abril de 2015.

SANTOS, Marlene S. dos. O discurso do poder matriarcal na comédia shakespeariana. Revista Scripta Uniandrade. Curitiba, PR. N. 7. p. 51, 2009.

SHAKESPEARE. William. Hamlet. Tradução Millôr Fernandes. São Paulo: Peixoto Neto, 2004.

TEIXEIRA, Maria Cecília Sanchez; ARAÚJO, Alberto Filipe. Gilbert Durand: imaginário e educação. Niterói: Intertexto, 2011.

WEEKS, Jeffrey. O Corpo e a Sexualidade. In: LOURO, Guacira Lopes (Org.). O Corpo Educado: pedagogias da sexualidade. Belo Horizonte: Autêntica, 2001. 